This PDF is a selection from a published volume from the National Bureau of Economic Research

Volume Title: Risk Topography: Systemic Risk and Macro Modeling

Volume Author/Editor: Markus Brunnermeier and Arvind Krishnamurthy, editors

Volume Publisher: University of Chicago Press

Volume ISBN: 0-226-07773-X (cloth); 978-0-226-07773-4 (cloth); 978-0-226-09264-5 (elSBN)

Volume URL: http://www.nber.org/books/brun11-1

Conference Date: April 28, 2011

Publication Date: August 2014

Chapter Title: Repo and Securities Lending

Chapter Author(s): Tobias Adrian, Brian Begalle, Adam Copeland, Antoine Martin

Chapter URL: http://www.nber.org/chapters/c12515

Chapter pages in book: (p. 131 - 148) 


\title{
Repo and Securities Lending
}

\author{
Tobias Adrian, Brian Begalle, Adam Copeland, \\ and Antoine Martin
}

\subsection{Introduction}

The markets for repurchase agreements (repos) and securities lending (sec lending) are part of the collateralized US-dollar-denominated money markets. The markets for repos and sec lending are crucial for the trading of fixed-income securities and equities. ${ }^{1}$ Repos are especially important for allowing arbitrage in the Treasury, agency, and agency mortgage-backed securities markets, thus enhancing price discovery and market liquidity. Securities lending markets play key roles in allowing shorting, both in fixedincome and equity markets. Given the essential role of these markets to the functioning and efficiency of the financial system, it is important to better understand and monitor repo and sec lending.

Tobias Adrian is a senior vice president and the head of the Capital Markets Function at the Federal Reserve Bank of New York. Brian Begalle is an assistant vice president at the Federal Reserve Bank of New York. Adam Copeland is a senior economist in the Money and Payments Studies Function at the Federal Reserve Bank of New York. Antoine Martin is a vice president and the head of the Money and Payments Studies Function at the Federal Reserve Bank of New York.

The authors thank Markus Brunnermeier, Michael Fleming, Ken Garbade, Frank Keane, Jamie McAndrews, and Arvind Krishnamurthy for constructive comments on earlier versions of this chapter. The views expressed in this chapter are those of the authors and do not necessarily reflect those of the Federal Reserve Bank of New York or the Federal Reserve System. For acknowledgments, sources of research support, and disclosure of the authors' material financial relationships, if any, please see http://www.nber.org/chapters/c12515.ack.

1. Krishnamurthy, Nagel, and Orlov (2012) offer a detailed comparison of these collateralized money markets. See Covitz, Liang, and Suarez (2013) for an excellent overview of the market for asset-backed commercial paper, which constitutes another important secured money market. 
- The key question addressed in this chapter is, what are the data requirements for monitoring repo and sec lending markets so as to inform policymakers and researchers about firm-level and systemic risk?

- One conclusion emerging from the chapter is the need to better understand the institutional arrangements in these markets.

- To that end, we find that existing data sources are incomplete. More comprehensive data collection would both deepen our understanding of the repo and sec lending markets and facilitate monitoring firm-level and systemic risk in these markets.

- Specifically, we argue that, at a minimum, six shared characteristics of repo and sec lending trades would need to be collected at the firm level: (a) principal amount, (b) interest rate (or lending fee for certain securities loan transactions), (c) collateral type, (d) haircut, (e) tenor, and (f) counterparty.

- In addition, we believe there would be value in collecting data at the firm level on the instruments in which securities lending cash collateral are invested. The reinvestment of cash collateral as practiced by securities lending agents potentially introduces a source of risk in addition to the "run" risk that also exists in repo markets.

These data would create a complete picture of the repo and sec lending trades in the market, allowing for a deeper understanding of the institutional arrangements in these markets and for accurate measurement of firm-level risk. Further, these data would allow for measures of the interconnectedness of the repo and sec lending markets, which would allow for better gauges of the systemic risk in these markets. The involvements of custodians, sec lending agents, and tri-party repo banks contribute to the riskiness of each transaction.

\subsection{Background on Repurchase Agreements and Securities Lending}

A repurchase agreement is the sale of securities coupled with an agreement to repurchase the securities, at a specified price, at a later date (see Duffie 1996; Garbade 2006). Securities lending agreements are economically similar to repo agreements. ${ }^{2}$ Both agreements resemble a collateralized loan, but their treatment under the US bankruptcy law is more beneficial to cash lenders: In the event of bankruptcy, cash lenders can typically sell their collateral, rather than be subject to an automatic stay as would be the case for a collateralized loan.

A repo or sec lending trade consists of six key variables: the size of the

2. For a detailed comparison of repo and sec lending agreements from a legal perspective, see Ruchin (2011). In practice, repos are used more often to finance fixed-income securities, while securities lending is used more often to obtain equities. 
transaction, the interest rate, the type of eligible collateral, the haircut, the maturity date, and the counterparties. The haircut corresponds to the difference between the value of the cash and the value of the collateral and is generally expressed as a percentage. For example, if $\$ 100$ of securities collateralizes a loan of $\$ 98$, the haircut is 2 percent. The level of haircut will typically reflect the quality of the collateral but may also vary by counterparty, reflecting the collateral provider's creditworthiness. The haircut can thus limit the counterparty credit risk exposure in secured borrowing transactions.

Repo and sec lending trades are conducted in over-the-counter markets that intermediate between borrowers and lenders, facilitating the exchange of securities and cash. ${ }^{3}$ Given that these are collateralized money markets, each transaction features a collateral provider and a cash lender. The motivation behind a specific repo or sec lending transaction can be either cash or security driven. A cash-driven transaction is one where the collateral provider is seeking to borrow cash. In such cases, the securities backing the transaction are typically "general collateral," meaning that they are part of a class of acceptable securities rather than a specific one. A security-driven transaction is one where the cash lender is seeking to borrow securities. In such cases, the security is usually specific.

Among the financial intermediaries that participate in repo and sec lending markets, two sets of institutions are crucial. First, clearing banks and custodial agents are primarily involved in the operations of the repo and sec lending markets. Second, security dealers are both lenders and borrowers owing to their role as market makers. In contrast to the repo market, custodians play a unique role in sec lending transactions.

A schematic of the US repo markets, provided in figure 9.1, highlights the extensive intermediation role played by securities dealers. ${ }^{4}$ For example, securities dealers intermediate between financial institutions that are long in cash, such as money market mutual funds, corporate treasuries, and custodial agents, and those institutions that are short in cash, such as hedge funds and other dealers. Repo markets are also used to reallocate securities both among securities dealers and between securities dealers and hedge funds, asset managers, and other financial institutions. The role of the clearing banks is hidden in figure 9.1 - they provide the operational support for the tri-party repo market (see the following section for details on that market).

Securities dealers also intermediate in the sec lending markets. In these markets, securities dealers are often borrowing securities from custodial agents and lending these same securities to hedge funds and other financial

3. Sec lending agreements can accommodate the exchange of securities for securities. In the United States, however, most sec lending transactions exchange securities and cash. This article focuses on this more common case.

4. See also Copeland, Davis, et al. (2012). 


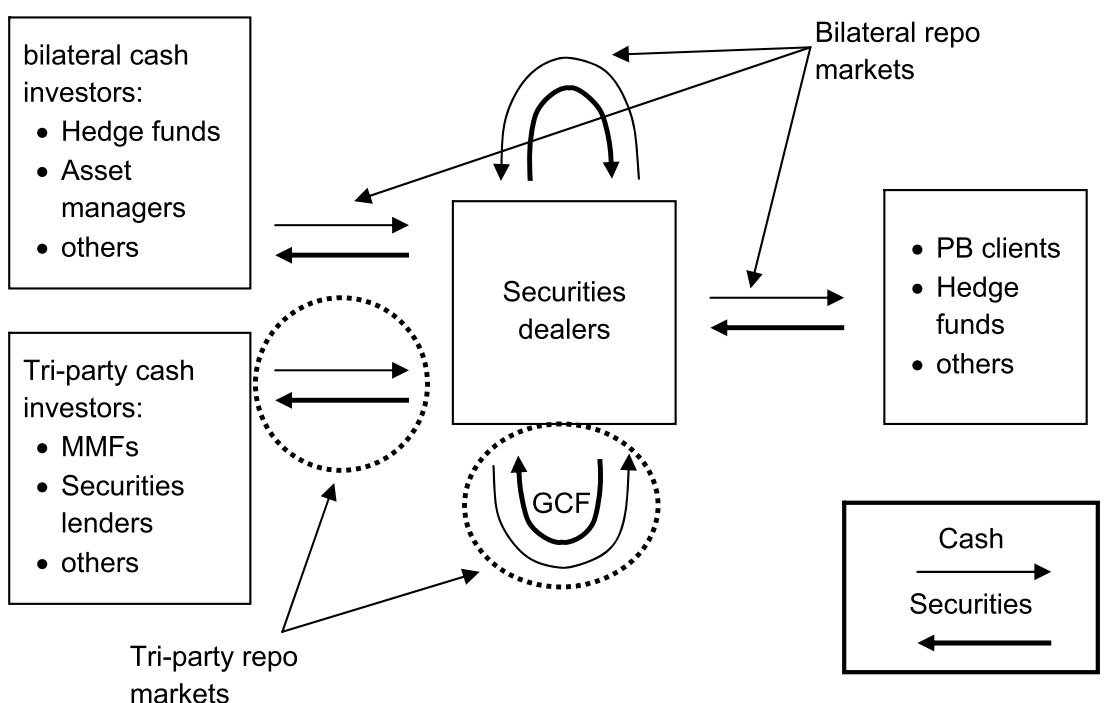

Fig. 9.1 US repo markets

Source: Copeland, Duffie, et al. (2012).

Notes: MMFs are money market mutual funds and $\mathrm{PB}$ is prime brokerage. GCF is the General Collateral Financing Repo ${ }^{\circledR}$ market run by the Fixed Income Clearing Corporation; this repo market is discussed in detail in section 9.3.3.

institutions. Part of the cash collateral that custodial agents acquire in the sec lending market is typically invested in the repo markets, creating an important link between the two markets. The custodial business is fairly concentrated: A few large players dominate the market as suppliers of general collateral and specific securities. Consequently, custodial agents are also large cash lenders in the market for repos.

While repo and securities loans may be open or term, most sec lending transactions are open. An open loan has an overnight tenor, but continues until one of the counterparties decides to cancel it. In particular, if the borrower returns the securities, the lender must return the cash collateral.

\subsection{The US Repo Markets}

\subsubsection{Overview}

It is useful to separate two broad classes of repos, distinguished by the way they are settled: bilateral and tri-party. Bilateral repos are repurchase agreements between two institutions where settlement typically occurs on a "delivery versus payment" basis. More specifically, the transfer of the collateral to the cash lender occurs simultaneously with the transfer of the 
cash to the collateral provider. Hence, the cash lender must have back-office capabilities to receive, track, value, and account for the securities. ${ }^{5}$

In a tri-party repo transaction, a third party provides a suite of collateral management and settlement services, such as settling the repos on its book, valuing the collateral, and making sure that the collateral adheres to the lender's eligibility requirements. Because settlement occurs on the books of a third party to whom collateral management has been outsourced, the cash lender does not need the back-office capability to take possession of the collateral.

Currently, the US tri-party repo market is set up to facilitate cash-driven transactions against general collateral. The services provided by the clearing banks make such repos less expensive for most investors than bilateral repos. In contrast, bilateral repos are usually used to obtain specific securities and raise cash against such securities, as the tri-party mechanism is not set up to facilitate the use of specific collateral.

\subsubsection{The Bilateral Repo Market}

The bilateral repo market provides for the exchange of cash and securities directly between collateral and cash providers. Use of this market may be preferable to other repo markets when two parties want to interact directly with each other, rather than through an agent, or if specific collateral is desired. Dealers use bilateral repos to provide cash to hedge funds, real estate investment trusts, banks, and other institutions, primarily through their prime brokerage activities. The collateral that dealers obtain in this fashion can in many cases be used as collateral in other repo markets (i.e., the collateral is "rehypothecated"), notably the tri-party repo market.

Bilateral repos are also common in the interdealer market, either as a source of funding or as a way to obtain specific securities. Dealers often serve as the custodian for their prime brokerage clients. In such cases, they settle bilateral repos through which they provide cash to these clients on their books. Interdealer bilateral repos are typically settled on the Fedwire Securities Service or through the Fixed Income Clearing Corporation (FICC). ${ }^{6}$ One of the benefits of settling with FICC is that the settlement of a dealer's repos, reverse repos, buy-sell transactions, and auction awards are netted (see Garbade and Ingber 2005).

\subsubsection{The GCF Repo® Market}

The GCF Repo ${ }^{\circledR}$ market is a blind-brokered interdealer market for Fedwire-eligible securities run by FICC. This is the market where most interdealer repo transactions occur. ${ }^{7}$ Fleming and Garbade (2003) provide

5. The cash lender can also hire its custodial bank to perform these services.

6. For more information on the FICC, see http://www.dtcc.com/about/subs/ficc.php.

7. For further information, see http://www.dtcc.com/products/fi/fixed_income_gsd/gcf _repo.php. 
an overview of the GCF Repo ${ }^{\circledR}$ market, which is part of the tri-party repo market because it settles on the books of the clearing banks. The FICC guarantees settlement as soon as it receives the data from the broker and compares the transaction.

To participate, dealers must be netting members of FICC's Government Securities Division. The GCF Repo ${ }^{\circledR}$ service enables dealers to trade general collateral repos based on rate, term, and underlying product, throughout the day without requiring intraday, trade-for-trade settlement on a deliveryversus-payment basis, which shifts settlement risk to the FICC netting members in aggregate.

\subsubsection{The Tri-party Repo Market}

The US tri-party repo market is set up to facilitate cash-driven transactions and serves as a key source of funding for securities dealers. Hence, the main collateral providers in the tri-party repo market are securities dealers - in particular, primary dealers. Some large hedge funds and other institutions with large portfolios of securities also borrow in the tri-party repo market, but they represent a small share of the total volume.

The cash lenders are more numerous and diverse than collateral providers. More than 4,000 individual firms are active as cash lenders. However, despite this large number, there is some concentration among cash lender types as money market mutual funds represent between a quarter and a third of the cash invested in the tri-party repo market, and securities lenders represent an additional quarter of cash invested. Securities lenders use the tri-party repo market to reinvest some of the cash collateral received from lending securities.

In the United States, the role of the third party is played by the two government securities clearing banks: J.P. Morgan Chase and the Bank of New York Mellon, which we also call tri-party agents. ${ }^{8}$ In addition to providing collateral management and settlement services, the clearing banks finance the dealers' securities during the day under current market practice. ${ }^{9}$ The intraday credit exposure results in high concentration risk of the clearing banks vis-à-vis tri-party repo borrowers. Specifically, clearing banks "unwind" the tri-party repo trades each day. The unwind consists of sending cash back to the lenders' cash accounts and the securities back to the collateral providers' securities accounts, respectively, on the balance sheet of the clearing bank. This exchange results in the clearing banks extending intraday credit to the collateral providers, since the securities are no longer

8. The number of US government securities clearing banks has decreased from nine in the early 1980s to two. This is likely due to economies of scales in this business that provide incentives for concentration.

9. Reforms are currently under way to reduce or eliminate this intraday exposure. See http:// www.newyorkfed.org/banking/tpr_infr_reform.html. 
financed by the tri-party cash lenders. The unwind facilitates the settlement of repos at the end of the day (Copeland, Duffie, et al. 2012).

\subsection{The US Securities Lending Market ${ }^{10}$}

\subsubsection{Overview}

In US equity markets, securities lending is driven primarily by the prohibition on "naked" short selling, which is a short sale by an institution that does not hold the security and therefore cannot complete delivery. ${ }^{11}$ The ban on naked short selling creates a role for securities lending, which allows an institution that wants to sell a security short to borrow it.

In US fixed-income markets, securities lending is used not only for short selling, but also for other borrowing transactions such as security-forsecurity arrangements. An institution may also want to borrow a security to hedge risk through the use of derivatives or to avoid "failing" on a delivery. Institutions also borrow securities to trade the repo rate itself; that is, if a Treasury security is trading special and a participant expects it to gain more specialness value, it will borrow that collateral for term and lend it overnight, hoping that the average overnight special repo rate is more attractive (lower) than the special repo rate it pays to borrow the security for term.

In the United States, most securities lending is done against cash collateral. Typically, the lender of a security pays an interest rate to the borrower for the cash collateral. The scarcer the security, the lower the interest rate paid by the securities lender. In addition to the return potentially generated through the lending transaction, lenders of securities seek to earn an additional return by investing the cash collateral. It should be noted that yield enhancement strategies embedded in the sec lending markets tend to be fundamentally different from plain repo transactions. In the sec lending markets, cash collateral is frequently invested in assets with characteristics that are very different from GC repo collateral, thus creating potential liquidity risk exposures.

The main lenders of securities are beneficial asset holders, such as pension plans, mutual funds, hedge funds, or insurance companies. These institutions typically own the securities outright and view sec lending as a way to enhance the yield of their security portfolios. Because the borrowing of securities is mainly for short selling, derivative hedging, or avoiding fails, the main borrowers are hedge funds, asset managers, option traders, and market makers.

10. Lipson, Sabel, and Keane (1990a, b) provide a comprehensive overview of the securities lending market.

11. For SEC regulation SHO, see http://www.sec.gov/divisions/marketreg/mrfaqregsho1204 htm. 
Custodian banks typically provide securities lending services (lending of securities as well as cash collateral reinvestment) to their clients, although some large beneficial asset holders may conduct these activities themselves. There are also some noncustodian third-party providers of these services. Prime brokers usually facilitate transactions for borrowers of securities.

\subsection{Crises in the Repurchase and Securities Lending Markets}

During the recent financial crisis, both the repo and sec lending markets experienced runs. This section describes what is known about these runs, highlighting the additional data required to better understand them.

\subsubsection{US Repo Markets}

Both the bilateral and tri-party repo markets experienced runs, but they were different in nature. In a repo market, an increase in haircuts can force a borrower to delever because a smaller amount of cash is raised with the same amount of securities. Hence, a repo market can experience a run if haircuts for all collateral classes increase by a large amount. ${ }^{12}$ Similarly, an asset class can experience a run if the haircuts for that particular asset class increase. A run on one or several asset classes seems to have happened in some bilateral repo markets during the crisis.

A different kind of run can occur in a repo market if haircuts do not increase. An institution that relies on a repo market for its funding may be forced into bankruptcy if its creditors refuse to extend repo financing. This seems to have happened to Bear Stearns and Lehman Brothers in the triparty repo market during the crisis, as lenders reacted to the perceived creditworthiness of the counterparty as opposed to the quality of the collateral.

Our knowledge of the events in these markets comes from recent empirical studies: Gorton and Metrick (2012) analyze haircuts in the bilateral market, while Copeland, Martin, and Walker (forthcoming) and Krishnamurthy, Nagel, and Orlov (2012) focus on the haircuts in the tri-party repo market.

These studies suggest that haircuts in the bilateral and tri-party markets behaved differently during the crisis. In the bilateral market, Gorton and Metrick show that haircuts increased rapidly and reached high levels. ${ }^{13}$ Hence, these authors argue that there was a generalized "run" on this repo market that reduced the amount of cash that could be raised by borrowers. Corroborating evidence for Gorton and Metrick's hypothesis is the high number of hedge fund failures due to margin calls. On July 31, 2007, two hedge funds operated by Bear Stearns filed for bankruptcy protection.

12. In addition, Adrian and Shin (2009), Brunnermeier and Pedersen (2009), and Ashcraft, Garleanu, and Pedersen (2010) suggest that haircuts are state variables for aggregate economic activity.

13. Different counterparties may have faced different haircuts in this market, but data are not available to support this view. 
Both were highly levered mortgage funds that were funded primarily in the repo markets. A closely related bankruptcy occurred on March 5, 2008, when Carlyle Capital Corporation failed to meet margin calls as a result of increases in repo haircuts. In the fall of 2008, many more hedge funds and shadow banks failed when they were unable to meet margin calls. These instances are labeled "repo runs" by Gorton and Metrick, though one could alternatively view them as forced deleveraging. ${ }^{14}$

In contrast, haircuts barely moved in the tri-party repo market, as documented in Copeland, Martin, and Walker (forthcoming). The difference between the haircuts in the bilateral and tri-party repo markets increased during the fall of 2008, peaked sometime in the first half of 2009, and fell back close to the level of July 2008 by the beginning of 2010 .

This evidence suggests no generalized run on the tri-party repo market, although Krishnamurthy, Nagel, and Orlov (2012) argue that there was a run on repo backed by nonagency MBS/ABS collateral. However, it appears that Bear Stearns and Lehman Brothers did experience runs, and the loss of funding in the tri-party repo market contributed to their difficulties. So in the case of the tri-party repo market, stress seemed to affect specific counterparties rather than the broad collateral classes, except perhaps the nonagency MBS/ABS.

Understanding the differences in behavior between the bilateral and the tri-party repo markets is important. Rising haircuts, while problematic in their own right, can be viewed as an equilibrating phenomenon (Martin, Skeie, and von Thadden, forthcoming). Indeed, increasing haircuts reduce the amount of funding borrowers can obtain, but this does not shut them out of the market altogether. In addition, if the increase in margins is gradual, it may give institutions time to adapt or find other sources of funding. In the tri-party repo market, the reduction in funding was precipitous, leaving little time for the firms to adapt.

Another difference between the bilateral and tri-party repo markets during this time was the creation of the Primary Dealer Credit Facility (PDCF) by the Federal Reserve following the Bear Stearns crisis of March 13, 2008 (see Adrian, Burke, and McAndrews 2009). The PDCF was created to backstop dealers funding in the tri-party repo market, and the set of eligible collateral was broadened over time. The PDCF may have prevented some runs on securities dealers, although it could not prevent the trouble experienced by Lehman. While the PDCF is designed to provide liquidity, it cannot prevent credit events due to solvency problems.

While the empirical studies discussed above present compelling evidence of the variety of behavior that occurs in repo markets, they also highlight

14. Adrian and Shin (2010) show that there is generally a close connection between repos and leverage of broker-dealers. The increase of haircuts in the bilateral market thus maps into the deleveraging of the broker-dealer sector following the Lehman bankruptcy and the concurrent decline of outstanding repos. 
the lack of comprehensive data. Gorton and Metrick (2012) analyze data on one firm's activities in one repo market segment, and Copeland, Martin, and Walker (forthcoming) describe quantity and haircut data on the tri-party repo market. Krishnamurthy, Nagel, and Orlov (2012) have collected firmlevel data on all six elements of the repo transactions, but, as they explain in their paper, these data are limited by their scope and frequency. This lack of data hinders a deep understanding of the drivers behind the different run dynamics observed in repo markets. Furthermore, the lack of data makes it much more difficult to evaluate the effectiveness of policy actions, such as the PDCF.

\subsubsection{US Securities Lending Markets}

As in the repo markets, aspects of the securities lending market behaved differently during the recent crisis. A broad deleveraging took place, creating liquidity stress and, in some cases, losses for securities lenders as they were forced to return the cash collateral to the borrowers of the securities. The liquidity stress and the losses were typically commensurate with the degrees of credit risk and liquidity transformation associated with the investment of cash collateral. Excessive speculation in cash reinvestment created extreme asset-liability mismatches, in what could have been a boring and safe activity (that is, investing only in Treasury GC repo).

The crisis surrounding AIG offers an example. Like many other large insurance companies, AIG engaged in securities lending. Before the financial crisis, its loans were mostly open and its pool of cash collateral was invested in particularly long-term and illiquid assets. This meant that AIG was performing considerable liquidity transformation, which can result in liquidity stress. This investment strategy yielded high returns before the crisis; however, it contributed to AIG's liquidity squeeze during the crisis. The firm experienced something similar to a run as borrowers of its securities sought to return them as part of the general market deleveraging that took place. The need to liquidate some illiquid assets to accommodate this return of securities contributed to a sizable share of AIG's losses. Maiden Lane II LLC was created to alleviate capital and liquidity pressures on AIG associated with the securities lending portfolios of several regulated US insurance subsidiaries of AIG. ${ }^{15}$

\subsection{The Economics of Collateralized Short-Term Lending and Data Needs}

The runs described in the previous sections suggest that understanding the fragility of repo and securities lending markets requires a good understanding of the institutional arrangements under which these contracts are

15. See http://www.newyorkfed.org/markets/maidenlane.html for more details. 
traded. This means that disaggregated data are particularly useful to understand market participants' reactions under stress.

Liquidity transformation is one of the key functions of financial intermediation. In general, intermediaries tend to be funded with short-term debt and tend to hold longer-term, relatively illiquid assets. This liquidity mismatch can give rise to fragility, as pointed out in the seminal contribution by Diamond and Dybvig (1983). However, the inefficiencies arising in this simple setup can be solved with a variety of policies or financial innovations. More recently, a rapidly growing literature has been focusing on fragility that is due to rollover risk (see Acharya, Gale, and Yorulmazer 2011; Brunnermeier and Oehmke 2013; and He and Xiong 2012).

The key concerns related to the repos and securities loans described in our examples are associated with the possibility of runs, which arise from liquidity transformation and their potential spillover, which can occur when institutions are interconnected. This suggests that data on the degree of liquidity transformation being performed, notably the tenor of repos and securities loans, are particularly important. The tenor of instruments in which cash collateral is reinvested is of additional importance, as is information about the interconnectedness of the participants engaged in these markets.

In addition to providing insights about the amount of maturity transformation, information about the tenor of an institution's funding can serve as an early warning system. Difficulty in renewing long-term funding typically signals that an institution is under stress. Longer-term funding gives the institution more time to find alternative sources of funding or to take other measures to improve its odds of survival. A longer-duration maturity profile also gives regulators more time to prepare for a potential rescue of the firm or an orderly unwind.

Repos are an important part, but not the only source, of funding for dealers. Getting a better picture of the various sources of dealer funding and how dealers are passing this funding on is important for our understanding of the sources of dealer fragility. For example, Duffie (2010) suggests three potential sources of "runs" on dealers: OTC derivative counterparties trying to reduce their exposure to dealers, loss of prime brokerage business, and a run on secured financing, including repo. Disclosure of cash management holdings could mitigate the potential for creating hidden vulnerabilities in the securities lending markets.

It is helpful to gauge the availability of different funding sources in times of stress and to know the extent to which different funding sources are substitutable. Understanding the differences in behavior between bilateral and tri-party repos contributes to that knowledge. In addition, understanding the extent to which financial market participants are interconnected can help us draw conclusions about the possible propagation of stress throughout the financial system.

Another potentially interesting source of data is the type of collateral 
being financed in repo markets. This information may provide some insights into the risk appetite of the institutions that fund dealers. Changes in the type of assets serving as collateral, or the introduction of new asset classes, can offer insights into the evolution of funding markets.

In addition to these data, information about rates and haircuts would also be useful - particularly information about interest rates and haircuts faced by dealers, given the critical intermediating role they play. Owing to the behavioral differences between the tri-party repo market and the bilateral repo market, interpreting those data could be difficult. Nevertheless, the data could help us understand these markets better and also provide interesting cross-sectional information about different dealers. Making cross-sectional data public, however, could raise disclosure issues.

\subsection{Existing Data and Data Gaps}

Both repo and securities lending transactions can be characterized by six pieces of information: principal, interest rate, collateral, haircut, tenor, and counterparty. For regulatory purposes, all six pieces of information are crucial for properly gauging systemic and firm-level risk. For example, in response to a rise in the perceived risk of a dealer seeking to finance its securities, cash lenders might ask for higher interest rates, higher-quality collateral, increased haircuts, shorter maturities, or all of these. Because they are heterogeneous, there is no standard response by cash lenders when faced with increased counterparty risk. As such, knowing a financial institution's counterparties is essential to understanding that firm's risk level.

Furthermore, counterparty information would allow regulators and researchers to measure the interconnectedness of a repo or securities lending market. An important goal for regulators is to understand how difficulties arising in a firm will impact other firms in the market, but this cannot be accomplished without information on counterparties. In addition, information about the cash reinvestment strategies of sec lending cash lenders is an important ingredient for assessing the riskiness of these transactions. This is in contrast to GC repo transactions, where counterparty information is less relevant owing to the liquidity of the collateral.

A number of data sources provide information on the six characteristics of repo and sec lending trades previously described. Following, we review which types of data on these characteristics are generally available to the public and discuss which additional data would need to be collected.

\subsubsection{Interest Rates}

A number of sources offer average interest rates on repo or sec lending transactions, conditional on the type of collateral offered and the tenor of the trade. Bloomberg, for example, provides daily averages of interest rates 
by tenor and collateral type for general collateral repo trades. Data Explorer offers similar average interest rate data based on sec lending transactions.

These public sources report interest rate data at the aggregate level and therefore do not provide the rates paid by individual firms. But interest rates often reflect the perceived risk level of the financial institution borrowing the cash. As such, we argue that collecting interest rate data for repo and sec lending trades at the firm level is important to understanding the risks in these markets.

A source of firm-level interest rate data is the SEC N-Q report filed by publicly traded money market mutual funds (MMFs). Although these data are not reported in a standardized form, MMFs generally report, by type, the total value of securities they have accepted as collateral for repo transactions, as well as information on haircuts, maturity, interest rates, and counterparties. Hence, these data provide a fairly detailed snapshot of MMF repo activities. Krishnamurthy, Nagel, and Orlov (2012) have started to collect and organize these data for the larger MMFs, focusing on the years encompassing the recent financial crisis. These data are promising because they provide firm-level information on all six characteristics of repo trades.

Obtaining these data for all major repo and securities lending firms would provide enough information to accurately measure firm-level and systemic risk in repo and sec lending markets. Unfortunately, these data on MMFs are limited in their scope and frequency. MMFs are a large source of cash in US repo markets, but they are far from being a majority - for example, they account for one-quarter to one-third of total cash invested in tri-party repo. The snapshots of activity are also fairly infrequent, with new data on a MMF arriving semiannually. Furthermore, these snapshots may not be representative of normal activity because these money funds may take into account that their repo transactions will be included in their Securities and Exchange Commission (SEC) reports (in other words, these data may suffer from the window-dressing problem).

\subsubsection{Principal and Collateral}

There are a number of data sources on the value of securities used in repo and sec lending transactions (i.e., the amount of collateral posted). Data Explorer offers a wealth of detailed information on the daily quantity of securities lending trades. As with interest rates, these data are available only at the market level, making it difficult to use them for monitoring individual firms.

Additional data on the value of securities used in repo and sec lending transactions are available from regular balance-sheet filings with the SEC. Every publicly traded company has to file quarterly 10-Q and annual 10-K reports. For financial institutions that participate in repo and sec lending transactions, the 10-Ks and 10-Qs will report those transactions to the extent 
that they occur on the balance sheet. While the $10-\mathrm{K}$ and $10-\mathrm{Q}$ reports contain balance-sheet data at the consolidated holding company level, the SEC also collects balance-sheet data on the subsidiaries of securities dealers. The US flow of funds relies on these reports in aggregating balance-sheet information on broker-dealers.

In early 2010, the SEC required money market mutual funds to file N-MFP reports. The data captured by this form contain, among other things, information on the securities a MMF accepts as collateral for repo transactions - in particular, the name of the security's issuer, the maturity date of the security, the coupon or yield, and value of the security. The form also reports haircuts (the ratio of the collateral value relative to the repo value), the maturity of the repo as determined under rule 2a-7 (taking maturity-shortening provisions and maturity-date extensions into account), and the interest rate of the repo.

The N-MFP report collects its data in a standardized manner, and the report is filed in an XML-tagged data format. Consequently, it will be fairly straightforward going forward to collect and analyze data on the collateral that MMFs are accepting in their repo transactions.

Moreover, the Federal Reserve form FR2004 assembles information on market activity from primary dealers. ${ }^{16}$ Primary dealers report the total value of securities purchased and sold through repo transactions by asset class. While the dealer-level data are confidential, aggregated information is made available to the public.

A relatively new source of information is provided by the Tri-Party Repo Infrastructure Reform website. ${ }^{17}$ This source reports, by asset class, the total value of securities that are posted as collateral in the tri-party repo market on the seventh business day of each month. Also reported is the total value of securities, by asset class, posted in the GCF Repo® market.

The above-mentioned data essentially provide snapshots of activity at the aggregate or firm level. But although interesting, these data do not provide sufficient information to answer many important questions about the repo and securities lending markets.

\subsubsection{Haircuts}

Information on haircuts is limited. Beyond the aforementioned SEC data on money market mutual funds, there is only aggregate data on haircuts in the tri-party repo market. Specifically, the Tri-Party Repo Infrastructure Reform website provides information on the distribution of haircuts.

16. See http://www.federalreserve.gov/reportforms/reportdetail.cfm?WhichFormId= FR_2004. For more information on primary dealers, see http://www.newyorkfed.org/markets /primarydealers.html. Adrian and Fleming (2005) provide an overview of the FR2004 data.

17. See http://www.newyorkfed.org/banking/tpr_infr_reform.html. 


\subsubsection{Tenor and Counterparty}

As far as we know, the only public source of information on tenor and counterparties is the aforementioned SEC N-Q report data filed by money market mutual funds.

In summary, a number of public data sources provide information on the interest rates and values of securities used in repo and securities lending trades. Much less is known about haircuts, tenor, and counterparties and the exact nature of cash reinvestment strategies in these markets. Unfortunately, it is often difficult or impossible to piece together the information at the firm level, and this is exactly the information needed to properly assess the risk level of a firm. While the overall amount of repo and sec lending trades of a firm is informative, the term structure of those trades is of first-order importance when assessing a firm's risk level. Similarly, counterparty, interest rate, and haircut information all significantly impact a firm's risk level. Consequently, it is important to collect this information at the firm level and in a comprehensive fashion.

In addition to the type of data just described, insight into the use of cash collateral provides value. As previously mentioned, cash collateral is frequently provided against securities lending transactions in the US market and that cash is reinvested to earn an additional return. Individual lenders determine the degree of reinvestment risk they desire; therefore, investments can be across a broad range of instruments of varying credit quality and tenor. Collection of data related to instrument type, credit rating (if applicable), and tenor can help identify the degree to which securities lending cash collateral is supporting other markets, as well as the degree of associated risk.

\subsection{Conclusion}

In a September 2012 speech, "Implications of the Financial Crisis for Economics," Federal Reserve Chairman Ben Bernanke distinguished between economic science, economic engineering, and economic management: ${ }^{18}$

Economic science concerns itself primarily with theoretical and empirical generalizations about the behavior of individuals, institutions, markets, and national economies. Most academic research falls in this category. Economic engineering is about the design and analysis of frameworks for achieving specific economic objectives. Examples of such frameworks are the risk management systems of financial institutions and the financial regulatory systems of the United States and other countries. Economic

18. The speech can be found at http://www.federalreserve.gov/newsevents/speech/bernanke 20100924a.htm. 
management involves the operation of economic frameworks in real time-for example, in the private sector, the management of complex financial institutions or, in the public sector, the day-to-day supervision of those institutions.

Chairman Bernanke goes on to add, "With that taxonomy in hand, I would argue that the recent financial crisis was more a failure of economic engineering and economic management than of what I have called economic science."

Our argument in this chapter is consistent with the Fed chairman's view and suggests that we need both better data and a better understanding of the institutional arrangements and the economic engineering by which key economic actors operate. The two go hand in hand. Good data help illuminate market functioning and can be useful for detecting changes in market practices that could increase risk. A good understanding of institutional arrangements may be necessary to make sense of the patterns identified by the data and can suggest the need for new data as market infrastructure evolves.

Better data are particularly important for understanding repo and securities lending markets and monitoring developments that may indicate stress. Such early warning signals can be the basis for policy decisions that aim at stabilizing the financial system. These are the money markets at the heart of the market-based financial system. While repo markets primarily enhance the efficiency of fixed-income markets, securities lending markets play central roles for both fixed-income and equity markets. Repo and securities lending markets are especially important for allowing arbitrage in the Treasury, agency, and agency MBS markets, thus enhancing price discovery, efficiency, and market liquidity. Securities lending markets play crucial roles in the shorting of securities. However, both markets also perform liquidity transformation roles and are thus exposed to the drying up of liquidity.

In the securities lending markets today, the degree of liquidity transformation is not reported in any transparent or systematic fashion, even when transactions involve large amounts of liquidity transformation. The repo market experienced liquidity shortages in the week prior to the Bear Stearns crisis, and the securities lending portfolio in Maiden Lane II illustrates the risk in liquidity mismatches of securities lending. The differences in behavior between the tri-party repo market and the bilateral repo market underscore this point. In the bilateral market, stress manifested itself in the form of a large and rapid increase in haircuts, creating a generalized run on the market. In the tri-party repo market, haircuts barely moved but some firms experienced dramatic decreases in the amount of financing they obtained in this market. Hence, the structure of each market, and the nature of their participants, appears to have an impact on how stress manifested itself. Understanding these differences remains important. 


\section{References}

Acharya, V., D. Gale, and T. Yorulmazer. 2011. "Rollover Risk and Market Freezes." Journal of Finance 66 (4): 1175-207.

Adrian, T., C. Burke, and J. McAndrews. 2009. "The Federal Reserve's Primary Dealer Credit Facility." Federal Reserve Bank of New York Current Issues in Economics and Finance 15(4).

Adrian, T., and M. Fleming. 2005. "What Financing Data Reveal about Dealer Leverage." Federal Reserve Bank of New York Current Issues in Economics and Finance 11(3).

Adrian, T., and H. S. Shin. 2009. "Prices and Quantities in the Monetary Policy Transmission Mechanism." International Journal of Central Banking 5 (4): 131-42. 418-37.

Ashcraft, A., N. Garleanu, and L. H. Pedersen. 2010. "Two Monetary Tools: Interest Rates and Haircuts." NBER Macroeconomics Annual 2010, vol. 25, edited by Daron Acemoglu and Michael Woodford, 143-180. Chicago: University of Chicago Press.

Brunnermeier, M. K., and M. Oehmke. 2013. "The Maturity Rat Race.” Journal of Finance 68 (2): 483-521.

Brunnermeier, M. K., and L. H. Pedersen. 2009. "Market Liquidity and Funding Liquidity." Review of Financial Studies 22 (6): 2201-38.

Copeland A., I. Davis, E. LeSueur, and A. Martin. 2012. "Mapping and Sizing the US Repo Market." Liberty Street Economics, June 25. http://libertystreeteconom ics.newyorkfed.org/2012/06/mapping-and-sizing-the-us-repo-market.html.

Copeland, A., D. Duffie, A. Martin, and S. McLaughlin. 2012. "Key Mechanics of the US Tri-Party Repo Market." Federal Reserve Bank of New York Economic Policy Review.

Copeland, A., A. Martin, and M. W. Walker. Forthcoming. "Repo Runs: Evidence from the Tri-Party Repo Market." Journal of Finance.

Covitz, D., N. Liang, and G. A. Suarez. 2013. "The Evolution of a Financial Crisis: Panic in the Asset-Backed Commercial Paper Market." Journal of Finance 68 (3): $815-848$.

Diamond, D., and P. Dybvig. 1983. "Bank Runs, Deposit Insurance, and Liquidity." Journal of Political Economy 91:401-19.

Duffie, D. 1996. "Special Repo Rates." Journal of Finance 51 (2): 493-526. 2010. How Big Banks Fail and What to Do About It. Princeton, NJ: Princeton University Press.

Fleming, M., and K. Garbade. 2003. "The Repurchase Agreement Refined: GCF Repo®.” Federal Reserve Bank of New York Current Issues in Economics and Finance 9(6).

Garbade, K. 2006. "The Evolution of Repo Contracting Conventions in the 1980s." Federal Reserve Bank of New York Economic Policy Review 12(1).

Garbade, K., and J. F. Ingber. 2005. "The Treasury Auction Process: Objectives, Structure, and Recent Adaptations." Federal Reserve Bank of New York Current Issues in Economics and Finance 11(2).

Gorton, G. B., and A. Metrick. 2012. "Securitized Banking and the Run on Repo." Journal of Financial Economics 104 (3): 425-51.

He, Z., and W. Xiong. 2012. "Rollover Risk and Credit Risk." Journal of Finance 67 (2): 391-429.

Krishnamurthy, A., S. Nagel, and D. Orlov. 2012. "Sizing up Repo.”NBER Working Paper no. 17768, Cambridge, MA. 
Lipson, P., B. Sabel, and F. Keane. 1990a. "Securities Lending, Part 1: Basic Transactions and Participants." Journal of Commercial Bank Lending 6:4-18.

1990b. "Securities Lending, Part 2: Regulation, Pricing, and Risks Borne by Participants." Journal of Commercial Bank Lending 7:18-31.

Martin, A., D. Skeie, and E.-L. von Thadden. Forthcoming. "Repo Runs." Review of Financial Studies.

Ruchin, Andre. 2011. "Can Securities Lending Transactions Substitute for Repurchase Agreement Transactions?" Banking Law Journal 128 (5): 450-80. 